\title{
The Stone-axe Factory of Graig-lwyd, Penmaenmawr.
}

T a meeting of the Royal Anthropological Institute held on April ig Mr. S. Hazzledine Warren presented a report on the results of excavations at Graig-lwyd carried out in June, I920, under a representative committee appointed by the Royal Anthropological Institute. The expenses of the excavation were met by grants from the National Museum of Wales, the Cambrian Archæological Association, and other public and private contributors.

The Neolithic workings follow the chilled margin of the Penmaenmawr intrusive rock for a considerable distance, but the excavation was mainly concentrated upon one important chipping "floor" associated with the site of a large hearth.

The workers made their stone axes either directly from the natural blocks of scree or indirectly by first striking off large flakes. These large primary flakes often weigh from $7 \mathrm{lb}$. to $14,1 \mathrm{~b}$., or even more, and their production in such a tough and intractable material is evidence of remarkable skill. "Core implements" and "flake implements" were made indifferently, according to convenience in working the stone. The stages of manufacture from the natural block to the finished axe may be grouped as (I) preliminary, (2) intermediate, and (3) advanced. The most characteristic forms arrested in the middle stage may be described as "intermediate ovates"; these might well be mistaken for Late Chelles and St. Acheul implements, while many of the smaller specimens in the preliminary stage resemble the earlier Chelles group. Pseudo-Mousterian flakes with faceted platforms, recalling the Levallois technique, were produced in large quantities as a waste product from the flaking of the axes. More than four hundred "ends of celts" (as they are usually called) were found, and thirty-two complete axes have been refitted from these halves broken during manufacture. The industry is essentially similar to that of Grime's Graves and Cissbury.

Four broken polished axes were recovered from the main "floor," and three of these had been rechipped after breakage into makeshift blades. One stone plaque engraved with a series of triangles was also discovered.

In opening a discussion on the report Sir William Boyd Dawkins said that a debt of gratitude was due to Mr. Warren for having brought these facts, the result of much hard work, before the institute. The subject was of the greatest interest and importance to British archæology at the present time. The finds at Graig-lwyd must be grouped with those from Cissbury and Grime's Graves. As a result of a careful comparison with the long series of finds from Cissbury in the Manchester Museum, he had come to the conclusion that every peculiarity in the Graig-lwyd specimens could be paralleled from Cissbury, the one difference being that the Graig-lwyd implements were made of igneous rock, while the Cissbury finds were flint. The Graig-lwyd specimens were consequently larger owing to the difference in material. The shape and the rude character of a specimen did not prove that it was not of Neolithic age. He him self had found at Trenton, New Jersey, side by side with typical Indian stone implements, specimens which in form belong to the Moustier and other European Palæolithic types. The lesson to be learned from this find was that age cannot be estimated from form. As regards the positive evidence for date of these ateliers, it was beyond question. At Cissbury Neolithic pottery and the remains of domestic animals had been found. The evidence from Grime's Graves was clear. There the flint from which implements were manufactured was taken from pits and galleries, and was therefore later in date than these, but the workings show that the greater number of these galleries had been excavated with polished stone axes, and therefore the implements of Chellean, Moustier, and other types found on this site were Neolithic. The conclusion to which this evidence pointed was supported by the types in Mr. Warren's find. The examples of specimens broken in course of manufacture in Neolithic times, of which the parts now reassembled by $\mathrm{Mr}$. Warren exhibited differences in patination, were also a proof that patination was no criterion of age. The discovery of this factory had an interesting bearing upon the question of prehistoric trade and communication. Owing to the existence of a felsitic stone implement factory in the Lake. District, he had hitherto derived the felsite axes found in the Midlands from this source, but in future the felsite at Graig-lwyd would have to be taken into account.

The implements from the Graig-lwyd excavations, which will be reproduced in illustration of the report when it is-printed in extenso, were exhibited at the Royal Anthropological Institute on April 20-22. A larger and more representative collection is to be exhibited at the rooms of the Society of Antiquaries, Burlington House, on May $23-25$.

\section{Descriptive Botany.}

UNDER the title "The Leguminous Plants of Hawaii " (issued by the Experiment Station of the Hawaian Sugar Planters' Association), Mr. J. F. Rock gives a systematic account of the native, introduced, and naturalised trees, shrubs, vines, and herbs belonging to the family Leguminosæ. Detailed descriptions are given of all the native and established species, with notes on distribution and economic uses; kevs to the genera and species are also included. In all, 200 species belonging to $7 \mathrm{I}$ genera are described, and there are 93 excellent full-page photographic reproductions of the more important species. The percentage of indigenous species in this family is very small, and of these only six are trees, one is a shrub, No. 2689 , voL. IO7] and the remainder are, with few exceptions, usually shore-plants or grow near the shore, and are distributed over most of the Pacific. Islands. This poor representation of one of the largest families of flowering plants contrasts remarkably with its rich representation in tropical Asia, and is a strong argument against the existence of any previous land connection with the Asiatic continent. The writer regards the Leguminosæ as a strong factor in proving the assumption that the Hawaian islands are purely oceanic in character; he proposes to discuss thoroughly the origin of the flora in a work on the phytogeography of the islands which he has in preparation.

In "Icones Plantarum Formosanarum," vol. ix. 